\title{
STUDI KOMPARASI KONSEP PENDIDIKAN ISLAM DALAM KELUARGA ABDURAHMAN AN-NAHLAWI DAN ZAKIAH DARADJAT
}

\author{
Andi Luqmanul Qosim ${ }^{1}$, Nurul Azmi Safitry ${ }^{2}$ \\ ${ }^{1}$ Fakultas Syariah IAIN Salatiga, Jawa Tengah \\ ${ }^{2}$ MTs Negeri 1 Temanggung, Jawa Tengah \\ Email : simanimza@gmail.com
}

\begin{abstract}
As Muslim, parents hold important role in applying Islamic education to educate their children. This is done to strengthen children's beliefs in Islam religion. However, in family education, many parents do not know the foundation, methods, and materials of Islamic education. The lack of understanding resulted in parents tend to use physical and psychological violence in educating their children. This situation raised concerns to Abdurrahman An-Nahlawi and Zakiah Daradjat. Both feels moved to conceptualize Islamic education in the family so that children from Muslim families can become the complete person' (insân kâmil). The comparative test of the two concepts shows that the differences in the basis, method, and material of the two can actually be an alternative for parents in applying education to their children. The outcome upon their children depend on the creativity of the parents in processing sources, methods, and materials in the concept of Islamic education from An-Nahlawi and Zakiah.
\end{abstract}

Keywords: Islamic Education, Family, Parents, Child

\begin{abstract}
Abstrak
Sudah sewajarnya sebagai umat Islam, para orang tua menerapkan pendidikan Islam dalam mendidik anak-anaknya. Hal ini dilakukan seiring untuk menguatkan keyakinan dalam beragama. Namun dalam pendidikan keluarga, banyak orang tua yang belum mengetahui landasan, metode maupun materi pendidikan Islam. Ketidaktahuan ini berdampak pada pola mendidik orang tua kepada anak dengan menggunakan kekerasan fisik maupun psikis. Keadaan ini mengundang keprihatinan bagi Abdurrahman AnNahlawi dan Zakiah Daradjat. Keduanya merasa tergugah untuk mengkonsepkan pendidikan Islam dalam keluarga agar anak-anak dari keluarga muslim dapat menjadi insân kâmil di masa mendatang. Uji komparasi dari konsep keduanya menunjukkan bahwa perbedaan landasan, metode dan materi dari keduanya justru dapat menjadi alternatif bagi para orang tua dalam mengaplikasikan pendidikan terhadap anakanaknya. Hasil terhadap anaknya tergantung pada kreatifitas para orang tua dalam mengolah sumber, metode dan materi dalam konsep pendidikan Islam dari An-Nahlawi dan Zakiah.
\end{abstract}

Kata Kunci: Pendidikan Islam, Keluarga, Orang Tua, Anak

\section{PENDAHULUAN}

Islam memiliki pandangan bahwa keluarga merupakan lingkungan yang paling berpengaruh terhadap pendidikan anak. Orang tua memegang peranan penting dalam pembentukan kepribadian anak. Baik dan buruknya kepribadian anak di masa mendatang lebih dominan ditentukan oleh pendidikan dan bimbingan dari orang tuanya. Di mana di dalam keluarga 
itulah anak pertama kali memperoleh pendidikan sebelum pendidikanpendidikan yang lain.

Akhir-akhir ini masih banyak ditemukan permasalahan seputar pendidikan anak. Di antaranya pemberitaan yang menceritakan tentang berbagai bentuk kekerasan yang dialami oleh anak, seperti kekerasan fisik, seksual, psikis, dan penelantaran. Bahkan hal ini sudah menjadi konsumsi keseharian masyarakat Indonesia melalui siaran televisi, media cetak maupun media online. Berbagai permasalahan ini merupakan cerminan dari buruknya pendidikan dalam keluarga di mana orang tua berperan sebagai pendidik utama di dalamnya.

Abdurrahman An-Nahlawi dan Zakiah Daradjat merupakan dua tokoh pendidikan yang telah mencurahkan pemikirannya ke dalam dunia pendidikan Islam. Keduanya berpandangan bahwa pendidikan Islam merupakan solusi dari berbagai permasalahan di dalam keluarga. Karena pendidikan Islam merupakan pendidikan yang bersumber pada kesempurnaan Ilahi sehingga sifat pendidikannya pun sempurna. AnNahlawi menawarkan solusi dari pendidikan dalam keluarga dengan metode Qur'ani dan Nabawi (An-Nahlawi, 1979: 113), sedangkan Zakiah dengan metode pembiasaan, keteladanan dan kisah/ bercerita (Daradjat, 2014: 38).

Keduanya mempunyai tujuan yang sama dalam mengkonsepkan pendidikan Islam, yaitu untuk membentuk anak menjadi manusia paripurna (insân kâmil). Walaupun bertujuan sama, mereka memiliki perbedaan di dalam mengkonsepkan pendidikan Islam mulai dari sumbernya metode dalam mendidik anak serta materinya. Perbedaan ini justru bisa menjadi alternatif bagi orang tua dalam mendidik anak-anaknya. Di mana setiap orang tua mempunyai kecenderungan tersendiri dalam memberikan pendidikan kepada anak-anaknya.

\section{METODE}

\section{Belum ada metode penelitian}

\section{PEMBAHASAN DAN HASIL}

\section{Profil Abdurrahman An-Nahlawi Dan Zakiah Daradjat}

a. Perjalanan Intelektual Abdurrahman An-Nahlawi

Abdurrahman An-Nahlawi (selanjutnya baca: An-Nahlawi) dilahirkan di Kota Damaskus, Syiria pada tanggal 1 Januari 1927. Abdul Karim Utsman adalah nama ayahnya. Ia sendiri yang mendidik serta mengasuh An-Nahlawi hingga dewasa. Perhatiannya terhadap pendidikan sangat besar sehingga ia menjadi panutan bagi An-Nahlawi, di samping karena ketaatannya menjalankan ibadah dan kepatuhannya mengamalkan ajaran Islam (Musmuallim, 2014: 78).

Sang ayah mengajari An-Nahlawi sejak dini tentang baca-tulis dan membaca kitab suci Al-Qur'an. Di sela-sela pembelajaran, sang ayah menyisipkan pembelajaran kepada putranya tentang ilmu-ilmu Islam yang mengarah pada pemahaman dan penafsiran Al-Qur'an. Tidak 
terbatas ilmu-ilmu agama, ia juga turut mengajarkan An-Nahlawi akan ilmu-ilmu umum (Noviyanty, 2010: 68).

Tentang pendidikan formalnya, An-Nahlawi tidak menyebutkan secara mendetail rentetan jenjang pendidikannya sejak berpisah dari didikan sang ayah. An-Nahlawi hanya menceritakan pendidikannya setelah ia tamat dari Madrasah al-Tsanawiyah (setingkat SMA) yaitu ketika mengenyam pendidikan di Universitas Darul Mu'allimin di Kota Damaskus. Pada awal perkuliahannya, ia mengambil jurusan filsafat. Namun dalam perjalanan intelektualnya, ia melanjutkan program magister dan doktoralnya di jurusan pendidikan Islam di universitas yang sama. Setelah lulus, ia diangkat menjadi dosen di tempatnya mengenyam pendidikan.

Konsentrasinya yang mendalam terhadap pendidikan Islam menariknya sebagai pengajar yang fokus di bidang tersebut. Ia diberikan amanah oleh pihak universitas untuk mengampu mata kuliah pendidikan Islam karena hasil pemikirannya yang dominan di dalamnya. Hal tersebut dapat dijumpai melalui karya-karyanya mengenai teori pendidikan Islam. Selain itu, ia juga mengenalkan metode pendidikan Islam yang didasarkan pada Al-Qur'an dan sunnah Rasulullah yang dikenal dengan metode Qur'ani dan Nabawi.

Sebagai seorang akademisi, An-Nahlawi juga menjadi pengajar di berbagai universitas di antaranya; (1) Dosen di Universitas Damaskus, (2) Dosen terbang di Perguruan Tinggi Ilmu dan Universitas Islam Imam Muhammad Ibnu Saud di Riyadh, (3) Peneliti di berbagai lembaga ilmiah di Damaskus, (4) Peneliti dan dosen pembimbing di Dinas Pendidikan Arab dan negara teluk, (5) Keynote speaker dalam diskusi serta (6) Penulis berbagai karya ilmiah.

Pengetahuan dan pengalamannya dalam pendidikan Islam menghantarkan An-Nahlawi untuk terus berinovasi. Selain mengajar, ia juga menyusun berbagai karya ilmiah dalam bentuk buku. Salah satunya adalah buku yang berjudul Ushûl al-Tarbiyah al-Islâmiyyah wa Asâlibihâ fi alBaiti wa al-Madrasati wa al-Mujtama'. Kontribusinya tidak hanya terbatas dalam wilayah pendidikan formal, namun juga non-formal. Dalam hal ini adalah pendidikan keluarga dan masyarakat seperti yang tertera dalam judul bukunya.

Sebagai pemikir pendidikan Islam, An-Nahlawi banyak menuangkan ide-ide atau gagasan briliannya dalam karya ilmiah. Di antara buku yang ditulisnya adalah: [1] Us ûl al-Tarbiyah al-Islâmiyyah wa Asâlibihâ fi al-Baiti wa al-Madrasati wa al-Mujtama', [2] Al-Tarbiyah alIjtimâ'iyyah fi al-Islâm, [3] Al-Tarbiyah bi al-Targî̀b wa al-Tarhîb, [4] AlTarbiyah bi al-Qisah, [5] Al-Tarbiyah bi al-'Ibrah, [6] A'lâmu al-Tarbiyah alIslâmiyyah fi al-Islâm, [7] Asasu al-Tarbiyah al-Islâmiyyah wa Uşûlu Tadrisihâ. Serta ada beberapa buku yang ditulis secara bersama-sama baik dalam bidang pendidikan, psikologi dan sosial.

b. Ekspedisi Intelektual Zakiah Daradjat

Zakiah Daradjat (selanjutnya baca: Zakiah) dilahirkan pada tanggal 
6 November tahun 1929 di desa Kotamerapak, Kecamatan Ampek Angkek, Bukittinggi, Sumatra Barat. Ia merupakan anak sulung dari pasangan suami istri Daradjat Ibn Husein yang bergelar Raja Ameh (Raja Emas) dan Rafi'ah binti Abdul Karim yang memiliki enam orang anak. Kedua orang tua Zakiah dikenal sebagai aktifis dalam kegiatan-kegiatan sosial. Ayahnya merupakan aktifis Muhammadiyah, sedangkan ibunya pegiat sosial di Partai Sarekat Islam Indonesia (PSII) (Nata, 2005: 233).

Dalam salah satu tulisannya, Zakiah menggambarkan keadaan masyarakat kampung di masa kecilnya yang senantiasa meninggalkan segala aktivitas untuk bergegas pergi ke masjid demi melaksanakan ibadah shalat secara berjamaah. Tingginya religiusitas ditambah dengan kehidupan keluarga yang bernafaskan Islam, tak heran jika sejak belia Zakiah telah mendapatkan dasar keagamaan yang kuat. Ia telah dibiasakan oleh sang ibu untuk menghadiri kegiatan pengajian-pengajian agama. Setelah masa kecilnya lewat, Zakiah tidak hanya sekedar menjadi pendengar, terkadang diminta untuk memberikan ceramah keagamaan (Hidayat, 1999: 5).

Pendidikan formal Zakiah dimulai sejak usianya menginjak enam tahun. Sebagai seorang aktifis yang kental keagamaannya, sang ayah menyekolahkan Zakiah di sekolah Standard School Muhammadiyah (setingkat SD) di Bukittinggi. Pada lembaga pendidikan ini, Zakiah pertama kali mendapatkan pendidikan formal berupa ilmu agama, ilmu pengetahuan, dan pengalaman intelektualnya. Semenjak belajar di lembaga pendidikan ini, Zakiah telah memperlihatkan minatnya yang cukup besar dalam bidang ilmu pengetahuan. Setelah tamat dari Standard School, Zakiah melanjutkan pendidikannya di dua tempat sekaligus yaitu di Kulliyatu al-Muballighât (setingkat SMP) dan SMP Negeri di Padang Panjang selama hampir enam tahun. Setelah tamat dari dua sekolah ini, Zakiah melanjutkan studinya ke Sekolah Menengah Atas (SMA) Pemuda di Bukittinggi (Nata, 2005: 234).

Ekspedisi intelektual sesungguhnya dimulai pada tahun 1951 setelah tamat SMA. Zakiah pergi merantau ke Yogyakarta untuk kuliah di Fakultas Tarbiyah Perguruan Tinggi Agama Islam Negeri (PTAIN)sekarang UIN Sunan Kalijaga-. Di samping mendalami ilmu agama, Zakiah juga mendalami ilmu umum dengan mengambil kuliah di Fakultas Hukum Universitas Islam Indonesia (UII). Akan tetapi, kuliahnya di UII harus berhenti di tengah jalan ketika ia memasuki tahun ketiga di PTAIN. Hal itu disebabkan karena teguran dari beberapa dosen yang memintanya untuk fokus kuliah di PTAIN (Hidayat, 1999: 6).

Setelah Zakiah mencapai tingkat doktoral satu (BA), ia bersama dengan sembilan orang teman laki-lakinya mendapat tawaran beasiswa dari Depag -sekarang Kemenag- untuk melanjutkan studinya ke Kairo. Pada tahun 1956, Zakiah bertolak ke Mesir dan mendaftarkan diri di Universitas 'Ain Shams Fakultas Tarbiyah dengan konsentrasi Special Diploma for Education, dan Zakiah diterima tanpa tes (Nata, 2005: 235).

Setelah itu Zakiah mengikuti program Magister pada jurusan 
spesialisasi Kesehatan Mental pada Fakultas Tarbiyah di Universitas yang sama. Program ini berhasil diselesaikan tepat waktu, yaitu selama dua tahun dengan tesis yang berjudul "Problematika Remaja di Indonesia" (Musykilat al-Murâhaqah fi Indonesia). Untuk menuntaskan pendidikan tingkat tingginya, Zakiah mengambil program doktoral pada universitas yang sama dengan mendalami lagi bidang psikologi, khususnya psikoterapi. Disertasi yang berhasil disusun dan dipertahankannya pada program doktoralnya ini berjudul "Perawatan Jiwa Untuk Anak-Anak." Dengan demikian, Zakiah telah menjadi seorang Doktor Muslimah pertama dalam bidang psikologi dengan spesialisasi psikoterapi (Nata, 2005: 236).

Pada dekade 1960-an, Zakiah tiba di tanah air. Setelah meraih gelar Doktor Psikologi, Zakiah langsung pulang ke Indonesia. Zakiah ditugaskan Saifudin Zuhri selaku Menteri Agama di Departemen Agama Pusat, di Jakarta, dengan pertimbangan agar Zakiah bisa mengajar di berbagai IAIN sekaligus. Sejak itu, Zakiah menjadi dosen keliling, dan ia tetap berkantor di Jakarta. Karena saat itu, UIN Sunan Kalijaga memintanya untuk kembali ke sana serta diminta untuk mengajar di IAIN Padang -sekarang UIN Imam Bonjol- dan IAIN Raden Fatah -sekarang UIN Raden Fatah- Palembang.

Pada 1967, Zakiah ditunjuk untuk menduduki jabatan Kepala Dinas Penelitian dan Kurikulum Perguruan Tinggi di Biro Perguruan Tinggi dan Pesantren Luhur. Pada 1977, ketika A. Mukti Ali menjabat sebagai Menag, Zakiah dipromosikan untuk menjadi Direktur di Direktorat Pendidikan Agama. (Burhanudin, 2002: 143-149). Pada tahun 1984, bersamaan dengan ditetapkannya sebagai Direktur Pascasarjana di IAIN Sunan Kalijaga Yogyakarta, Zakiah dikukuhkan sebagai guru besar (Profesor) dalam bidang Ilmu Jiwa Agama IAIN. Secara akademis lengkap sudah ia sebagai ilmuwan Islam yang memiliki keahlian yang handal dalam bidangnya (Nata, 2005: 237).

Selain menjadi pendidik, psikolog, dan mubalighah, Zakiah adalah seorang penulis yang produktif. Ia telah menghasilkan banyak karya baik di bidang pendidikan, psikologi, dan agama. Beberapa judul karya ilmiah Zakiah tercantum dalam buku "70 Tahun Prof. Dr. Zakiah Daradjat". Secara klasifikasi penerbit, PT. Bulan Bintang menerbitkan 16 judul buku, Gunung Agung 3 judul buku, YPI Ruhama 10 judul buku, Pustaka Antara 3 judul buku, karangan bersama ada 4 judul untuk bahan ajar tingkat SD hingga perguruan tinggi, dan proyek bersama yang juga untuk bahan ajar ada 12 judul buku yang terbit di berbagai penerbitan.

\section{Konsep Pendidikan Islam Dalam Keluarga}

Secara teoritis, tidak ada perbedaan mendasar antara konsep pendidikan Islam di sekolah maupun di dalam keluarga (khususnya mengenai sumber, tujuan, metode dan materi). Pendidikan Islam di sekolah dan keluarga saling berkaitan antara satu dengan lainnya. Namun pada tataran praktis, keduanya memiliki perbedaan-perbedaan dalam penerapannya. 
Dalam pandangan Moh. Haitami Salim, proses pendidikan dalam keluarga secara teknis berbeda dengan pendidikan formal di sekolah. Orang tua sebagai pendidik tidak memiliki Rencana Pelaksanaan Pembelajaran (RPP), tindakan yang dilakukan oleh orang tua di rumah dalam penerapan metode pendidikan menggunakan langkah-langkah praktis. Umumnya orang tua tidak mengenal nama-nama dan jenis metode pendidikan, apalagi secara teoritis. Namun, secara praktis orang tua melakukan proses pendidikan di rumah dengan cara-cara tertentu, yang jika diidentifikasi sesungguhnya bukanlah metode yang asing dari bermacam-macam metode pendidikan yang dikenal secara teoritis di sekolah (Salim, 2013: 255).

Abudin Nata juga memiliki gagasan mengenai hal ini. Menurutnya, pendidikan Islam yang dilaksanakan dalam keluarga tidak dibakukan secara formal sebagaimana pendidikan di sekolah yang telah dibakukan dengan adanya kurikulum. Materi pendidikan Islam dalam keluarga pada umumnya berkaitan dengan penanaman keimanan yang benar, bimbingan membaca dan menghafal Al-Qur'an, pendidikan ibadah, dan juga pendidikan akhlak mulia (Nata, 2010: 190).

Dengan demikian, dapat dikatakan bahwa pendidikan Islam dalam keluarga secara praktis berbeda dengan pendidikan di sekolah. Pendidikan Islam dalam keluarga dilaksanakan sesuai dengan pemahaman orang tua dalam mendidik anak-anaknya. Meskipun demikian, pendidikan dalam keluarga mempunyai peranan penting dalam membentuk kepribadian anakkarena orang tua merupakan teladan pertama anak. Oleh karena itu, orang tua harus memiliki pemahaman yang benar dalam mendidik anakanak agar dapat membimbing mereka memiliki kepribadian yang baik.

a. Konsep An-Nahlawi Tentang Pendidikan Islam Dalam Keluarga

1) Sumber Pendidikan Islam

Pendidikan Islam merupakan kebutuhan mutlak bagi manusia supaya mereka dapat melaksanakan syari'at Islam sesuai dengan kehendak Allah. Berdasarkan pernyataan ini, An-Nahlawi menyimpulkan bahwa sumber syari'at Islam dan pendidikan Islam itu sama, yakni Al-Qur'an dan as-Sunah.

a) Al-Qur'an

Al-Qur'an merupakan sumber utama pendidikan Islam, karena di dalam Al-Qur'an Allah telah menurunkan tuntunan pendidikan kepada umat manusia. Sebagai sumber utama pendidikan Islam, Al-Qur'an memberikan dampak edukatif kepada Rasulullah dan para sahabatnya. Hal itu tampak dalam kehidupan Rasulullah dan para sahabat yang tidak hanya mempelajari Al-Qur'an sebagai ilmu semata, tetapi juga mengamalkan kandungan Al-Qur'an dalam kehidupan mereka.

Menurut An-Nahlawi, dalam memberikan keterangan kepada pembaca ataupun pendengar, Al-Qur'an beranjak dari hal-hal konkrit yang dapat disaksikan dan diakui oleh panca indra manusia, seperti hujan, angin, tumbuh-tumbuhan, petir, dan kilat. 
Tidak hanya itu, Al-Qur'an juga menekankan tentang hal-hal dogmatis, seperti keharusan mengakui wujud, keagungan, kekuasaan, dan sifat sempurna Allah. Semua itu kadangkala diungkapkan dengan kalimat bertanya, baik yang dimaksud dengan memberikan perhatian, membuat senang, mengingatkan, maupun dengan maksud-maksud lain yang dapat merangsang kesan-kesan rabbâni, seperti: tunduk, bersyukur, cinta dan khusyuk kepada Allah. Setelah itu baru disajikan berbagai macam ibadah dan tingkah laku ideal untuk menerapkan akhlak rabbâni secara praktis (An-Nahlawi, 1979: 21-22).

Pendapat An-Nahlawi mengenai metode Al-Qur'an dalam memberikan keterangan tersebut sejalan dengan pendapat Quraish Shihab yang menyebutkan bahwa dalam memberikan materi, Al-Qur'an membuktikan kebenaran materi tersebut melalui bukti-bukti argumentasi yang dikemukakan oleh AlQur'an sendiri maupun yang dapat dibuktikan oleh akal manusia. Hal ini dimaksudkan agar manusia merasa bahwa ia berperan dalam menemukan hakikat materi yang disajikan sehingga merasa memiliki dan bertanggungjawab akan hal tersebut (Shihab, 2009: 273).

b) As-Sunah

Sebagai sumber pendidikan Islam kedua, An-Nahlawi memandang bahwa as-Sunah mempunyai dua faidah besar dalam wilayah pendidikan, yaitu: (a) Menjelaskan sistem pendidikan Islam secara komprehensif yang terdapat di dalam Al-Qur'an (b) Menyimpulkan metode pendidikan dari kehidupan Rasulullah bersama para sahabatnya, perlakuan terhadap anak-anak, serta proses penanaman keimanan (An-Nahlawi, 1979: 23-24).

Pendapat An-Nahlawi di atas, seirama dengan pendapat Samsul Nizar. Menurutnya seluruh keteladanan yang diberikan oleh Nabi merupakan sumber dan acuan yang dapat digunakan oleh umat Islam dalam seluruh aktivitas kehidupannya. Untuk itu diperlukan as-Sunah sebagai penguat dan penjelas hukum-hukum yang terkandung dalam Al-Qur'an sekaligus sebagai pedoman bagi kemaslahatan kehidupan manusia dalam semua aspek termasuk pendidikan Islam (Nizar, 2001: 98).

2) Metode Pendidikan Islam dalam Keluarga

An-Nahlawi mencoba menggali prinsip-prinsip metode pendidikan yang terdapat di dalam Al-Qur'an dan as-Sunah. Dari hasil penelusurannya itu, ia menemukan berbagai macam metode pendidikan yang dapat menggugah perasaan dalam rangka menanamkan rasa iman dan cinta kepada Allah, rasa nikmatnya beribadah, rasa hormat kepada orang tua, dan sebagainya.

Metode pendidikan An-Nahlawi ini telah banyak dikaji oleh para tokoh pendidikan, salah satunya adalah Ahmad Tafsir. Menurut Ahmad Tafsir, metode pendidikan An-Nahlawi belum 
banyak dikenal dalam buku-buku Barat, di antaranya adalah tentang cara menanamkan rasa iman, rasa cinta kepada Allah, rasa nikmatnya beribadah (salat, puasa, dan lain-lain), rasa hormat kepada orang tua dan sebagainya (Tafsir, 2010: 136).

Adapun metode pendidikan qur'ani dan nabawi menurut AnNahlawi sebagai berikut:

Pertama, Metode Hiwar (dialog). Metode hiwar ini terinspirasi dari dialog antara Allah dengan hamba-Nya. Seperti, Allah memanggil hamba-Nya dengan mengatakan, "Wahai, orangorang yang beriman," dan hamba-Nya menjawab dalam kalbunya, "Kusambut panggilan Engkau, Ya Rabbi." Terkadang terjadi hal sebaliknya, terdapat dalam beberapa ayat Al-Qur'an bahwa orang mukminlah yang berbicara kepada Allah dalam keadaan berdoa (An-Nahlawi, 1979: 185-186).

An-Nahlawi memandang ayat-ayat tersebut sebagai bentuk hiwar. Dialog antar Tuhan dengan hamba- Nya ini menjadi petunjuk bahwa dialog ini dapat digunakan sebagai metode pendidikan. Karena metode ini merupakan metode pendidikan yang digunakan Allah sebagai Maha Guru dalam mendidik hamba-Nya, maka logikanya, orang tua yang notabene sebagai pendidik dalam keluarga pun dapat menggunakan metode tersebut dalam mendidik anak-anak mereka (Tafsir, 2010: 137).

Kedua, Metode kisah Qurani dan Nabawi. Menurut AnNahlawi, kisah qur'ani dan nabawi bukan hanya semata kisah atau semata-mata karya seni yang indah. Melalui metode kisah ini, Allah juga mendidik manusia agar beriman kepada-Nya. Selain itu tujuan terpenting dari kisah qur'ani dan nabawi adalah pendidikan akhlak melalui pelukisan watak manusia secara nyata yang mampu mengajak pendengar atau pembaca untuk menghayati dan meneladaninya (An-Nahlawi, 1979: 210).

Ketiga, Metode Qudwah (Keteladanan). Anak-anak cenderung untuk meneladani orang tua selaku pendidiknya dalam bertindak. Hal ini telah diakui oleh semua pakar pendidikan baik dari Barat maupun dari Timur. Secara psikologis, anak memang senang meniru, tidak saja perkara yang baik, tetapi yang juga perkara yang buruk. Sifat meneladani ini diakui dalam Islam. Umat meneladani Nabi dalam beribadah, sebagaimana shalat, puasa dan haji. Nabi meneladani Al-Qur'an. Aisyah pernah berkata bahwa akhlak Rasulullah itu adalah Al-Qur'an. Pribadi Rasulullah adalah interpretasi Al-Qur'an secara nyata. Tidak hanya dalam perkara ibadah, perkara kehidupannya sehari-hari pun merupakan contoh tentang cara hidup yang islami (An-Nahlawi, 1979: 234-235).

Keempat, Metode Latihan dan Pengamalan. Salah satu metode yang digunakan oleh Rasulullah dalam mendidik para sahabat ialah metode latihan dan pengamalan (pembiasaan). Para sahabat 
mempelajari cara berwudhu Rasulullah dan cara Rasulullah mengoreksi mereka atau saling membetulkan di antara para sahabat kemudian mereka akan mengamalkan cara berwudhu yang benar ini setiap kali hendak mengerjakan shalat. Rasulullah pun menggunakan metode ini untuk menguatkan hafalan. Rasulullah mengulang-ulang do'a dan ayat yang sama sehingga para sahabat hafal kemudian meminta para sahabat memperdengarkannya kepada Rasulullah untuk diluruskan jika terdapat kekeliruan dalam bacaan (An-Nahlawi, 1979: 240).

Kelima, Metode 'Ibrah dan Mau'idhah, An-Nahlawi memandang ibrah dan mau'idzah keduanya merupakan metode pendidikan yang masing-masing mempunyai dampak pedagogis. Pendidikan dengan metode 'Ibrah hendaknya mencakup seluruh materi pengajaran baik agama maupun non agama mengingat hakikat dari pendidikan Islam yang meliputi segala aspek (AnNahlawi, 1979: 244). Adapun Mau'izoh merupakan sajian bahasan tentang kebenaran dan kebajikan dengan maksud mengajak orang yang dinasihati untuk menjauhkan diri dari bahaya dan membimbingnya ke jalan yang berbahagia dan berguna baginya. Dalam makna lain, mau'izoh berarti tażkir (peringatan) yaitu hendaknya orang yang menasihati berulang kali mengingatkan agar membangkitkan perasaan dan motivasi untuk segera beramal shalih, menaati Allah, dan melaksanakan segala perintahNya. Pengaruh yang paling penting dari metode ini adalah penyucian jiwa anak sehingga anak akan berperilaku luhur dan menjauhi segala bentuk kemungkaran (An-Nahlawi, 1979: 253).

Keenam, Metode Targhîb dan Tarhîb. Metode pendidikan Islam ini didasarkan atas fitrah manusia,yaitu sifat keinginan kepada kesenangan, keselamatan, dan tidakmenginginkan kesengsaraan. Targî̉b dan Tarhîb dalam pendidikan Islam berbeda dengan metode ganjaran dan hukuman pada umumnya (An-Nahlawi, 1979: 256-257). Ahmad Tafsir dalam Mahmud menjelaskan perbedaan mendasar dari metode An-Nahlawi ini dengan metode ganjaran dan hukuman adalah metode Targîib dan Tarhîb bersandar kepada penjelasan ayat-ayat Allah, sedangkan ganjaran dan hukuman bersandar pada ganjaran dan hukuman duniawi (Musfah, 2009: 119).

3) Materi Pendidikan Islam dalam Keluarga

Kunci pendidikan dalam keluarga pada hakikatnya terletak pada pendidikan agama pada anak. Berkaitan dengan ini, Ahmad Tafsir berpendapat, sebagaimana yang dikutip Moh. Haitami Salim, terdapat dua kegunaan pendidikan agama dalam keluarga. [1] Penanaman nilai dalam arti pandangan hidup yang kelak akan mewarnai perkembangan jasmani dan rohani anak. [2] Pembinaan sikap yang kelak menjadi asas dalam berinteraksi dengan sesama (Salim, 2013: 203). 
Adapun materi pendidikan agama yang hendaknya diajarkan oleh orang tua kepada anak menurut An-Nahlawi, yaitu:

Pertama, Pengajaran Al-Qur'an. Materi ini meliputi; [a] mengajarkan cara membacanya dengan benar dan baik, [b] mendorong anak untuk menghafal ayat-ayat Al-Qur'an, terutama surat-surat pendek yang ada di juz 30/ Juz 'Amma. [c] membiasakan anak untuk membaca Al-Qur'an di rumah. Contohnya setelah shalat Magrib dan shubuh (An-Nahlawi, 1996: 184).

Kedua, Penanaman Keimanan. An-Nahlawi memandang bahwa keimanan merupakan pondasi utama pendidikan Islam. Penanaman keimanan dimulai dari menjelaskan tujuan tertinggi pendidikan Islam, yakni menjelaskan makna ulûhiyyah, rubûbiyyah dan makna ub̂idiyyah yang tidak boleh disandarkan kepada selain Allah. Artinya, orang tua mempunyai kewajiban untuk menjauhkan anaknya dari segala bentuk kemusyrikan agar tidak menodai kesucian keyakinannya semenjak kecil (An-Nahlawi, 1996: 118).

Ketiga, Mendidik Akhlak dan Ibadah Praktis. Materi ini kemudian dijelaskan oleh Moh. Haitami Salim dengan penjelasan yang lebih aplikatif. Menurutnya, Ibadah praktis diajarkan orang tua kepada anak sebagai bentuk pengamalan keimanan kepada Allah. Ibadah tidak sebatas menjadi pengetahuan anak, tetapi perlu adanya pengamalan yang istiqomah (Salim, 2013: 212).

Keempat, Pengajaran Budaya Islam. Materi pengajaran budaya Islam perlu diajarkan kepada generasi muslim untuk memisahkan antara budaya Islam dengan budaya non-Islam. Bagi An-Nahlawi, kebudayaan non-islami banyak yang berusaha menyimpangkan jiwa anak agar meragukan dan menjauhkan budaya Islami. Bentuk-bentuk penyimpangan itu dapat masuk dari berbagai aspek untuk menyilaukan dan mengaburkan budaya Islami.

b. Konsep Zakiah tentang Pendidikan Islam dalam Keluarga

1) Sumber Pendidikan Islam

Zakiah memandang, landasan yang digunakan sebagai pedoman dalam pelaksanaan pendidikan Islam bersumber dari AlQur'an dan As-Sunah serta dapat dikembangkan melalui jalan Ijtihad. (Daradjat, 2014: 19).

a) Al-Qur'an

Al-Qur'an merupakan kitab pendidikan yang menjadi rujukan utama dalam menentukan prinsip-prinsip pendidikan Islam. Dikatakandemikian, karena di dalam Al-Qur'an terdapat banyak ajaran mengenaiprinsip-prinsip yang berkenaan dengan kegiatan dan usaha pendidikan. Sebagai bukti, Zakiah menyebutkan isi dalam Q.S. Luqman ayat 12-19 membicarakan tentang prinsip 
materi pendidikan yang terdiri dari masalah iman, akhlak, ibadah, sosial, dan ilmu pengetahuan. Bukti lain dalam Q.S. al-Alaq ayat 1-5 merupakan wahyu pertama yang diturunkan kepada Rasulullah berkaitan dengan pendidikan. Allah membuka surat itu dengan kata 'iqra' yang berarti 'bacalah'. Dengan kata lain pendidikan Islam harus berlandaskan ayat-ayat Al-Qur'an yang penafsirannya dapat dilakukan melalui jalan ijtihad disesuaikan dengan perubahan dan perkembangan zaman (Daradjat, 2014: 20).

Oleh karena itu, pendidikan Islam dalam keluarga harus melaksanakan proses pendidikannya sesuai dengan asas pendidikan yang terdapat di dalam Al-Qur'an. Abdul Qadir Djaelani menegaskan bahwa keluarga Muslim harus senantiasa manjadikan rumah mereka dalam suasana yang penuh rasa keagamaan. Suasana ini bisa diperoleh dengan mempelajari sumber ajaran dan pendidikan Islam, yakni Al-Qur'an secara intensif (membaca dan mempelajari isi kandungannya) oleh setiap anggota keluarga (Djaelani, 1995: 233).

b) As-Sunah

As-Sunah adalah segala perkataan, perbuatan, ataupun pengakuan yang disandarkan kepada Nabi Muhammad. Rasulullah adalah pendidik sejati bagi seluruh umat. Abdul Madjid Khon menjelaskan bahwa di dalam as-Sunah banyak ditemukan materi pendidikan Islam yang harus diajarkan kepada anak, seperti keimanan, keislaman, akhlak, Al-Qur'an, fikih, keterampilan mengendarai kuda, keterampilan berenang, dan lain sebagainya (Khon, 2014: 2).

Selain itu, jika kita menengok kembali sejarah kehidupan Rasulullah beserta para sahabatnya, kita akan dapati bahwa Rasulullah senantiasa menggunakan berbagai strategi dalam mendidik. Di antaranya; a) menggunakan rumah Arqam bin Arqam sebagai tempat proses pengajaran Rasulullah kepada para sahabat, b) para tawanan perang diberi kewajiban untuk mengajar baca tulis kepada para sahabat yang masih buta huruf, c) Rasulullah mengirim para sahabat ke daerah- daerah yang penduduknya baru memeluk Islam. Semua strategi ini merupakan upaya Rasulullah dalam rangka memberikan pendidikan Islam kepada seluruh umatnya (Daradjat, 2014: 21).

i. Ijtihad

Ijtihad dalam bidang pendidikan merupakan upaya yang dilakukan oleh para pakar pendidikan dengan segenap ilmu yang mereka miliki untuk menghasilkan teori-teori pendidikan yang baru sesuai dengan kebutuhan zaman. Hal ini harus tetap sejalan dengan Al-Qur'an dan as-Sunah. Upaya ini dipandang perlu sebab ajaran Islam yang terkandung dalam Al-Qur'an dan asSunah adalah bersifat pokok dan prinsip. Di samping itu, ajaran Islam telah tumbuh dan berkembang melalui ijtihad. Hal ini 
merupakan sebuah tuntutan dari perubahan kondisi sosial yang senantiasa berubah (Daradjat, 2014: 21-22).

2) Metode Pendidikan Islam

Metode pendidikan adalah cara yang digunakan untuk mencapai tujuan pendidikan. Menurut Zakiah metode pendidikan haruslah sesuai dengan perkembangan psikologis anak didik. Seorang pendidik dalam hal ini orang tua tidak cukup sekedar memiliki ilmu pengetahuan semata, tetapi ia harus memahami metode pendidikan dan juga psikologi anak, supaya ia dapat mendidik anaknya dengan baik (Daradjat, 1988: 130). Berikut beberapa metode pendidikan menurut Zakiah:

Pertama, Metode Keteladanan. Metode ini merupakan metode yang lebih efisien dan efektif dalam menanamkan nilai-nilai ajaran Islam kepada anak. Karena secara psikologis anak memang senang meniru, tidak hanya perkara baik, tetapi yang jelek pun mereka tiru (Salim, 2013: 48). Hal ini juga dikemukakan oleh Said Mursi, baginya "Anak kecil akan selalu meniru orang dewasa, khususnya orang tua atau gurunya dalam hal baik maupun tidak baik." (Mursi, 2004: 11). Oleh karena itu, orang tua harus bisa mencontohkan perilaku yang baik dan menjadi teladan bagi anak-anaknya.

Zakiah memandang metode keteladanan ini sangat tepat digunakan dalam mendidik anak pada usia dini. Karena pada usia tersebut pertumbuhan kecerdasan anak masih bersifat inderawi. Sebagai contoh anak sering melihat orang tuanya melaksanakan shalat, berdo'a dengan khusyuk, dan bergaul dengan sopan santun. Adanya kecenderungan meniru dan unsur identifikasi di dalam jiwa si anak akan membawanya untuk meniru orang tuanya (Daradjat, 1995: 47).

Kedua, Metode Pembiasaan dan Latihan. Pembiasaan adalah sesuatu yang dilakukan secara berulang-ulang agar sesuatu itu dapat menjadi kebiasaan. Menurut Zakiah, hendaknya orang tua menyadari bahwa dalam pembinaan pribadi anak sangat diperlukan pembiasaan dan latihan yang cocok sesuai dengan perkembangan anak. Dengan pembiasaan dan latihan ini akan terbentuk sikap tertentu pada anak, yang lambat laun sikap itu akan menjadi jelas dan kuat, sehingga tidak tergoyahkan lagi karena telah melekat menjadi bagian dari pribadinya (Daradjat, 1996: 62).

Pendidikan dengan metode ini dapat dimulai dengan hal-hal yang sederhana misalnya membaca bismillah tiap kali memulai pekerjaan seperti makan, minum, dan lain-lain yang terdapat aktivitas anak sehari-hari. Selain itu juga memperkenalkan Tuhan secara sederhana sesuai dengan kemampuannya (Daradjat, 1998: 132).

Ketiga, Metode Cerita. Metode ini merupakan metode pendidikan yang bertumpu pada bahasa, baik lisan maupun tulisan. Metode ini disebut juga dengan metode berkisah. Cerita pada dasarnya bersifat penyampaian pesan dari sumbernya kepada pihak yang memerlukan. Dalam al-Qur'an banyak sekali kita temukan ayat-ayat tentang nasihat 
dan cerita mengenai rasul dan nabi terdahulu sebelum Nabi Muhammad. Dengan metode ini diharapkan akan mampu meningkatkan keimanan anak untuk berbuat amal kebaikan dalam kehidupannya (Ramayulis dan Nizar, 2009: 227).

3) Materi Pendidikan Islam

Materi pendidikan Islam dalam lingkungan keluarga tentunya berbeda dengan materi pendidikan Islam di sekolah. Materi pendidikan Islam dalam keluarga menurut Zakiah merupakan materi pendidikan yang pernah diterapkan oleh Luqman al-Hakim kepada anaknya, sebagaimana termaktub dalam Al-Qur'an surah Luqman ayat 12-19, di antara materi-materi tersebut adalah:

Pertama, Pembinaan Keimanan. Menurut Zakiah, tubuh yang kuat dan sehat yang disertai dengan akal, ilmu pengetahuan dan teknologi yang canggih tidak akan pernah menjadikan seseorang merasa puas, bahkan sulit untuk merasakan kebahagiaan bila tidak disertai dengan dimensi iman. Iman yang dapat memberikan ketenteraman batin dan kebahagiaan adalah iman yang benar menurut agama yang telah ditumbuhkan sejak kecil dan telah menyatu ke dalam kepribadian.

Pembinaan keimanan didapatkan anak dengan nasehat, perilaku dan teladan dari orang tuanya. Di samping itu juga bisa dari mendengar lantunan ayat suci Al-Qur'an yang dibacakan oleh kedua orang tuanya, hiasan dinding yang bernafaskan Islam, kebiasaan orang tua membaca basmalah dan hamdalah dalam melaksanakan setiap pekerjaan. Lambat laun nilai-nilai keimanan yang diberikan oleh orang tua melalui keteladanan tersebut akan ditiru oleh anak kemudian menjadi bagian dari kepribadiannya (Daradjat, 1995: 54-57).

Kedua, Pembinaan Akhlak. Akhlak adalah implementasi dari iman dalam segala bentuk perilaku. Di antara contoh akhlak yang diajarkan oleh Luqman al-Hakim kepada anaknya adalah: 1) Akhlak anak terhadap kedua orang tua, 2) Akhlak terhadap orang lain, 3) Akhlak dalam penampilan diri.

Akhlak anak terhadap orang tua dan orang lain banyak tergantung pada sikap orang tua terhadap anak. Apabila anak merasa telah terpenuhi semua kebutuhan pokoknya, maka anak akan sayang, menghargai, dan menghormati kedua orang tuanya. Akan tetapi apabila sebaliknya, misal ia merasa dibenci atau suasana keluarga yang tidak tenteram, dan lain sebagainya, maka perilaku anak tersebut dapat bertentangan dengan yang diharapkan oleh orang tuanya sebagai bentuk protes anak akan keadaan yang tidak menyenangkan itu (Daradjat, 1995: 58-60).

Ketiga, Pembinaan Ibadah. Pembinaan ketaatan beribadah pada anak juga dimulai dalam lingkungan keluarga. Anak yang masih kecil tertarik dengan kegiatan ibadah yang mengandung gerakan. Pengalaman ibadah yang menarik bagi anak di antaranya shalat berjamaah, ikut berbuka puasa, suasana shalat tarawih pada bulan 
Ramadhan dan shalat hari raya di mana ia berpakaian baru bersama teman-temannya merupakan pengalaman ibadah yang tidak mudah terlupakan. Bahkan sampai tua nanti (Daradjat, 1995: 60-62).

Gagasan Zakiah di atas senada dengan Ahmad Tafsir. Menurutnya, dalam melaksanakan tugas sebagai pendidik pertama dan utama bagi anak dalam keluarga, orang tua hendaknya belajar dari Luqman al-Hakim yang kisahnya abadi di dalam Al-Qur'an. Materi pendidikan yang diberikan Luqman kepada anaknya sebagai berikut. [1] pendidikan ketauhidan, yang mencakup mensyukuri nikmat, meyakini pembalasan, dan melarang bentuk kemusyrikan. [2] pendidikan akhlak, yang mencakup akhlak kepada orang tua dan masyarakat. [3] pendidikan shalat. Anak harus mengerjakan shalat sebagi salah satu tanda kepatuhan kepada Allah (Tafsir, 2014: 190).

\section{Perbedaan Gagasan Antara An-Nahlawi Dan Zakiah}

Dalam membahas sub bab ini, penulis mendapati beberapa perbedaan konsep An-Nahlawi dan Zakiah terkait pendidikan Islam dalam keluarga. Oleh karena itu, terdapat empat poin yang akan penulis bahas di dalam komparasi perbedaan konsep antara kedua tokoh tersebut.

Sumber Pendidikan Islam. Perbedaan pada sumber pendidikan Islam dalam keluarga dimiliki oleh Zakiah tentang ijtihad. Zakiah memandang bahwa ijtihad bisa diaplikasikan sebagai sumber pendidikan Islam mengingat ijtihad merupakan proses berfikir dalam menyelesaikan masalah. Masalah-masalah dalam bidang pendidikan terasa semakin kompleks seiring dengan perkembangan zaman dan kondisi sosial. Oleh karena itu, ijtihad dalam bidang pendidikan merupakan tuntutan yang harus dipenuhi dalam menyelesaikan berbagai masalah pendidikan. Prinsip-prinsip pendidikan yang terdapat dalam Al-Qur'an dan as-Sunah dijadikan sebagai landasan untuk berijtihad supaya tidak keluar dari koredor keduanya.

Dengan demikian, ijtihad bisa menjadi jalan keluar dari pelbagai problem pendidikan yang ada dengan mengembangkankonsep pendidikan secara kreatif dan inovatif sesuai dengan perkembangan zaman. Begitupula pendidikan Islam dalam keluarga juga dapat dikembangkan melalui ijtihad. Saat ini banyak terdapat teori-teori mengenai pendidikan Islam dalam keluarga yang merupakan hasil ijtihad para pakar pendidikan Islam, seperti Zakiah Daradjat, Abdurrahman an-Nahlawi, Abdullah Nashih Ulwan, dan lainnya.

Metode Pendidikan Islam. An-Nahlawi mempunyai kelebihan dalam hal metode pendidikan Islam dalam keluarga, yaitu dengan metode Hiwâr (dialog). Baginya, metode dialog dilakukan antara kedua belah pihakuntuk melakukan tanya jawab yang di dalamnya terdapat kesatuan topik. Bila dilaksanakan dengan baik, metode ini akan memberikan dampak positif kepada anak dengan mengambil pelajaran setelah dialog selesai.

Selain itu An-Nahlawi juga memiliki metode Targhîb dan Tarhîb. Metode pendidikan ini diaplikasikan oleh para orang tua dalam mendidik 
anak-anak mereka dengan menjelaskan kepada anaktentang janji Allah akan kenikmatan surga apabila beramal shalih dan juga ancaman akan siksa neraka apabila berbuat dosa. Metode ini bertujuan agar anak merealisasikan segala perintah dan larangan Allah dalam kehidupannya. Agaknya metode pendidikan An-Nahlawi ini bertolak belakang dengan pendapat Zakiah. Menurut Zakiah dalam mendidik anak, hendaknya orang tua mendekatkan anak-anak kepada Allah dengan menonjolkan sifat pengasih dan penyayangNya. Dengan menonjolkan sifat-sifat Allah yang memberi keamanan bagi jiwa anak, seperti Yang Pengasih, Penyayang, Penolong, Pelindung, dan sebagainya. Hal tersebut akan membantu perkembangan sikap positif anak terhadap Allah. Orang tua juga sebaiknya tidak menonjolkan segi-segi yang menakutkan seperti azab kubur, siksa neraka, dan lain sebagainya yang berkesan negatif bagi anak. Karena dengan rasa takut itu, anak akan berbalik menjadi tidak takut dan cenderunguntuk meninggalkan ajaran agama ketika ia remaja (Daradjat, 1996: 61).

Materi Pendidikan Islam. Dalam materi, Zakiah justru tidak sekreatif An-Nahlawi. Karena An-Nahlawi mempunyai dua materi yang berbeda dari Zakiah yaitu; Al-Qur'an dan budaya Islam. Bagi An-Nahlawi, AlQur' an harus diajarkan kepada anak sejak dini. Pengajaran Al-Qur'an dapat dilakukan dengan melakukan pendampingan terhadap anak. Sehingga selain memperoleh ilmu membaca dan menghafal Al-Qur'an, anak juga mendapatkan pemahaman yang betul akan makna dan maksud dari ayat yang dibacanya.

An-Nahlawi juga memandang bahwa budaya Islam perlu diajarkan kepada generasi muslim untuk memisahkan antara budaya Islam dengan budaya non-Islam. Karena kebudayaan non-Islam banyak yang berusaha menjauhkan budaya Islami. Kekhawatiran An-Nahlawi cukup berdasar. Di mana sekarang ini telah terjadi banyak penyimpangan yang terwujud dalam; (1) Ilmu pengetahuan, yaitu penghambaan kepada alam dan menyandarkan segala hukum-hukumnya pada kekuatan alam dengan mengabaikan Allah sebagai pencipta dan pengendali alam semesta ini. Pendapat ini senada dengan pendapat Sidi Gazalba yang menegaskan bahwa pengetahuan tentang apa yang ada di langit dan di bumi berguna untuk menumbuhkan iman kepada Allah yang telah menciptakan dan mengatur alam. Adapun bagi mereka yang tidak beriman, pengetahuan itu tidak memberi keterangan dan peringatan. Karena dengan akalnya, ia mencari-cari jawaban filsafat tentang apa yang ada di alam ini sehingga menyandarkannya pada kekuatan alam (Gazalba, 1978: 285).

(2) Kesenian, yang dimaksud untuk membangkitkan nafsu birahi. Orang tua hendaknya memberikan pemahaman kepada anak bahwa berbagai bentuk kesenian tersebut bertentangan dengan budaya Islam. Hal ini agar anak tidak menganggap menonton, menikmati, ataupun membuat kesenian tersebut sebagai suatu hal biasa.

Bagi An-Nahlawi, materi Al-Qur'an dan budaya Islam sangat penting dimasukkan ke pendidikan Islam dalam keluarga. Tanpa pengajaran Al- 
Qur'an kepada anak, maka anak hanya akan memahami Islam sebagai status belaka tanpa ada pengamalan, dalam hal ini adalah membaca dan menghafalkan Al-Qur'an serta mengamalkan isinya. Adapun materi budaya Islam diberikan orang tua kepada anak untuk meng-counter budaya-budaya non-Islam yang dapat masuk dalam fikiran maupun kebiasaan anak. Sehingga sejak awal anak akan tahu mana budaya yang boleh diterimanya dan mana yang harus ditolaknya.

\section{KESIMPULAN}

Berdasarkan kajian di atas, konsep pendidikan Islam dalam keluarga dari pemikiran An-Nahlawi dan Zakiah bisa menjadi solusi untuk para orang tua dalam mendidik anaknya supaya menjadi insân kâmil. Mereka bisa menjadikan pendidikan Islam sebagai acuan utama dalam mendidik anakanaknya karena sumbernya yang otoritatif dari Al-Qur'an dan As-Sunnah. Jika dirasa kurang, Zakiah menambahkan ijtihad sebagai landasan alternatif mengikuti perubahan sosial yang begitu cepat.

Adapun metode dan materi dari keduanya bersifat simbiosis mutualisme. Artinya metode dan materi dari An-Nahlawi dan Zakiah bisa dipraktekkan supaya bisa saling melengkapi sesuai dengan kebutuhan pendidikan anak dalam keluarga. Di mana setiap anak memiliki kecenderungan masing-masing dalam menerima metode maupun materi yang berkaitan dengan pendidikan Islam. Tentunya dibarengi dengan kreatifitas para orang tua dalam mengolah materi, baik itu dari pengajaran Al-Qur'an, penanaman keimanan, pembinaan akhlak, pembiasaan ibadah serta pengenalan budaya Islam.

\section{DAFTAR PUSTAKA}

An-Nahlawi, Abdurrahman. 1979. Ushûl al-Tarbiyah Al-Islâmiyyah wa Asâlibihâ fi al-Baiti wa al-Madrasati wa al-Mujtama'. Damaskus: Dar Al-Fikr. 1996. Prinsip-Prinsip dan Metode Pendidikan Islam dalam Keluarga di Sekolah dan di Masyarakat. Alih bahasa oleh Herry Noer Aly. Cet. III. Jakarta: CV. Diponegoro.

Burhanudin ed, Jajat. 2002. Ulama Perempuan Indonesia. Jakarta: PT. Gramedia Pustaka Utama.

Daradjat, Zakiah. 1988. Kesehatan Mental. Cet. XIII. Jakarta: CV. Haji Masagung. CV. Ruhama. 1995. Pendidikan Islam Dalam Keluarga dan Sekolah. Cet. II. Jakarta: . 1996. Ilmu Jiwa Agama. Cet. XV. Jakarta: Bulan Bintang.

Daradjat dkk, Zakiah. 2014. Ilmu Pendidikan Islam, Cet. XI. Jakarta: Bumi Aksara

Djaelani, Abdul Qadir. 1995. Keluarga Sakinah. Surabaya: PT. Bina Ilmu. 
Enny Noviyanty, "Metode Pendidikan Islam (Analisis Perbandingan Pemikiran Al-Ghazali dan Abdurrahman An Nahlawi)," Tesis pada Pascasarjana UIN Sultan Syarif Kasim Pekanbaru, Pekanbaru , 2010

Gazalba, Sidi.1978. Asas Budaya Islam. Jakarta: Bulan Bintang

Helmawati. 2014. Pendidikan Keluarga Teoritis dan Praktis. Bandung: PT. Remaja Rosdakarya

Hidayat, Komarudin. 1999. Perkembangan Psikologi Agama dan Pendidikan Islam di Indonesia; 70 Tahun Prof. Zakiah Daradjat. Ciputat: PT. Logos Wacana Ilmu.

Jejen Musfah, Metode Pendidikan dalam Perspektif Islam, TAHDZIB Jurnal Pendidikan Agama Islam, Vol. 3, No. 1, 2009

Khon, Abdul Majid. 2014. Hadits Tarbawi. Cet. II. Jakarta: Kencana Prenada Media Group.

Mursi, Muhammad Said. 2004. Seni Mendidik Anak. Jakarta: Pustaka Al-Kautsar Musmuallim, "Pendidikan Islam di Keluarga dalam Perspektif Demokrasi (Studi Pemikiran Hasan Langgulung dan Abdurrahman An Nahlawi," Tesis pada Pascasarjana UIN Sunan Kalijaga Yogyakarta, Yogyakarta, 2014

Nata, Abuddin. 2005. Tokoh-Tokoh Pembaharuan Pendidikan Islam di Indonesia. Jakarta: PT.Raja Grafindo Persada. 2010. Ilmu Pendidikan Islam, Jakarta: Kencana Prenada Media

Nizar, Samsul. 2001. Pengantar Dasar-Dasar Pemikiran Pendidikan Islam. Jakarta: Gaya MediaPratama.

Ramayulis dan Samsul Nizar. 2009. Filsafat Pendidikan Islam. Jakarta: Kalam Mulia

Salim, Moh. Haitami. 2013. Pendidikan Agama dalam Keluarga, Yogyakarta: ArRuzz Media.

Shihab, M. Quraish. 2009. Membumikan Al-Qur'an. Cet. III. Bandung: PT. Mizan Pustaka

Tafsir, Ahmad. 2010. Ilmu Pendidikan Dalam Perspektif Islam. Cet. X. Bandung: PT. Remaja Rosdakarya

2014. Ilmu Pendidikan Islam, Cet. XI. Bandung: PT. Remaja Rosdakarya.

Thobroni, A., 2019, Pendidikan Keluarga Dalam Perspektif Hukum Islam (Studi Kasus Wanita Karir), Al-Fikri: Jurnal Studi dan Penelitian Pendidikan Islam, 2(1), 61-72. doi:http://dx.doi.org/10.30659/jspi.v2i1.4016 